\title{
Implementation Evaluation of International Community Services as Special Program in Physic Education Study Program Faculty of Teacher Training and Education Universitas Ahmad Dahlan
}

\author{
Dian Artha Kusumaningtyas ${ }^{\mathrm{a},{ }^{*}}$, Eko Nursulistiyo $^{\mathrm{b}}$, Ariati Dina Puspitasari ${ }^{\mathrm{c}}$ \\ ${ }^{a}$ Physic Education Study Program, Universitas Ahmad Dahlan Yogyakarta \\ ${ }^{b}$ Physic Education Study Program, Universitas Ahmad Dahlan Yogyakarta \\ cPhysic Education Study Program, Universitas Ahmad Dahlan Yogyakarta \\ *Corresponding author: dian_uad@yahoo.com
}

Article history

Received: 10/10/2016

Received in revised form: 14/01/2017

Accepted: 04/03/2017

\begin{abstract}
This research purpose is to evaluate the International Community Services (KKN Internasional) as a special program at Physics Education department of Faculty of Teacher Training and Education ( FKIP) Universitas Ahmad Dahlan (UAD). Research method which is used in this research base on CIPP evaluation model (Context, Input, Process, Product). The research subjects are Physics Education department of UAD, the International Office Affairs (KUI) of UAD, the Community Service Department (LPM) of UAD, and the student participant of KKN International on 2013, 2014, and 2016. Questionnaires are used to collect the data. The result of this research, context is in $85 \%$ on very good category, input is in $81 \%$ on very good category, process is in $82 \%$ on very good category, and product is in $92 \%$ on very good category according to majority of research subjects. This program is recommeded to continue with some suggestion such as development the guide book of KKN Internasional, etc.
\end{abstract}

Keywords: evaluation, KKN International, special program, physics education of UAD. 


\subsection{INTRODUCTION}

Colleges as a place to produce next generation have a task to prepare its students to have competencies which is required in this era. Permendikbud No. 812014 have set their Companion Certificate Letter or SKPI (Surat Keterangan Pedamping Ijazah) as a letter that explains the various competences and skills possessed by a graduate of a college in addition to grand predicate academic number in student transcript. With this SKPI, the user can find out more detail about the ability of their worker candidate.

Various attempts were made in higher education/college. Universitas Ahmad Dahlan (UAD) particulary in physics education departmentdid it too. Physics Education special programs was drawn up to prepare for that condition. One of them is the International Community Service Program (KKN International) in department of physic education UAD.

KKN is a form of education by providing learning experiences for students to live in the middle of the community outside the campus and directly identify and address issues of the facing development. KKN carried out by universities as an effort to improve the content and weight of education for students and to obtain greater added value in college (LPM UAD, 2014). Service learning is a means to providing students with real-life experiences in a situated learning environment (Prasart,2016). Two strategies of seven strategies by Drs. Martinez and McGrath that give deeper learning by $21^{\text {st }}$ century teacher are connect learning to real world experiences and extend learning beyond the school (Monica et all, 2016). KKN can bring university students to gain lot of experienced in real world to get deeper learning.

KKN International in physics education department which have been implemented third period (3 years) from 2013 to 2015, collaborated with University of Neuva Caceres Lab School and Bicol Islamic Education Foundation Filipina (2015). While in Cambodia placed in the village of Phum V, District Khleang Svay, Kampong Cham province (2013). KKN Internasional serves to know the cultures, sharing knowledges, foreign language proficiency test and as a form of da'wa in other countries for students who did it.

Efforts to enhance and improve the flagship program of this study program,are done by research to evaluate the program. The evaluation research is a study conducted aims for decision-making by comparing an event, activity and standard products and programs that have been established based on the phenomenon. (Sudarsono, 1994). According to Endang (2016), the benefits of evaluation of the program are: (1) Improving the methods used to identify a program that is always consistent with its intended (2) Assuring the level of success that may be obtained from the program, and help choose a strategy the most suitable in order to achieve its intended purpose, (3) determine whether the implementation of programs that can reach people who were targeted (beneficiary), (4) assess whether the implementation of the program was able to achieve predetermined objectives, and (5) Measure the impact of the program on development (education, economy and defense) on a wide scale.

KKN International program is very important to be evaluated to compliance with the guidelines of international of KKN which have been made by Community Service Department or Lembaga Pengabdian Masyarakat (LPM), including whether the registration procedures, departure procedures, preparations to be made, implementation, and withdrawal of KKN students are in accordance with applicable regulations or not. With these activities, the study programwill know everything as an effort to repair this flagship program.

Evaluation of the flagship program is also important not only to improve to the program but also in order to realize the vision, mision and objectives of physic education department of UAD. According to the Strategic Plan and operational procedure of Physic Education UAD, one priority on 
the development of physic education courses is development of human resources which in the context of this research is the KKN International students and stakeholders.

\subsection{METHODOLOGY}

The research used to obtain information about the organization of the KKN International in Physics Education Study program UAD, include in evaluative research type. The concept of evaluation performed is using the CIPP (Context, Input, Process, Product) model. According to Stufflebeam (2007), the evaluation essentially to improve a program of activities such as education, management, project, program or institution. Various educational programs have been conducted using this model, such as those related to science and mathematics education, rural education, educational research and development, school improvement, professional development schools and many more (Norazilawati, 2016).Hence, the context, input, process and product evaluation should support the planning, structuring, implementing and recycling of decisions respectively (Nor, 2016).

Adapted from Nana Sudjana and Ibrahim (2004), the scope of the implementation evaluation of the KKN Internasional includes components:

Context, access the needs of the institution and activity problems of student in KKN International.

Input, include the readiness of facilities / infrastructure, as well as funding support.

Process, including the quality in the implementation program and participation of participant in supporting the implementation of the program.

Product, including the quality of the result of KKN Internasional program.

The steps in conducting this study, refers to Sukardi, DewaKetut, and Nila Kusumawati (2008), is as follows,

1. Determine the scope of the activities in KKN Internasional that will be evaluate

2. Develop design evaluation program

3. Develop instruments

4. Carry out assessment / data collection

5. Implement data analysis

6. Compile the results / conclusions ratings

7. Giving recommendations to the relevant institutions

8. Develop a program evaluation report

Table 1. Conversion of actual score to four scale value

\begin{tabular}{cccc}
\hline No & Score range & Value & Category \\
\hline 1 & $\mathrm{Mi}+1,5 \mathrm{SDi} \leq \mathrm{M} \leq \mathrm{Mi}+3,0 \mathrm{SDi}$ & $\mathrm{A}$ & Very Good \\
\hline 2 & $\mathrm{Mi}+0 \mathrm{SDi} \leq \mathrm{M}<\mathrm{Mi}+1,5 \mathrm{SDi}$ & $\mathrm{B}$ & Good \\
\hline 3 & $\mathrm{Mi}-1,5 \mathrm{SDi} \leq \mathrm{M}<\mathrm{Mi}+0 \mathrm{SDi}$ & $\mathrm{C}$ & Good Enough \\
\hline 4 & $\mathrm{Mi}-3 \mathrm{SDi} \leq \mathrm{M}<\mathrm{Mi}-1,5 \mathrm{SDi}$ & $\mathrm{D}$ & Bad \\
\hline
\end{tabular}

Where :
$\mathrm{M}=$ Score obtained
$\mathrm{Mi}=$ Ideal Mean $=1 / 2($ Maximum score + minimum score $)$
$\mathrm{SDi}=$ Ideal Standardeviation $=1 / 6$ (Maximum score - minimum score)

Maximum score $=$ Sum of Items number $\mathrm{x}$ maximum score

Minimum score $=$ Sum of Items number $\mathrm{x}$ minimum score

The research instrument is a questionnaire which will be given to research subjects. Research subjects are Physics Education Study Program UAD, LPM UAD, International Office Affair or Kantor Urusan Internasional (KUI) UAD and the students who did KKN International in 2013, 2014, 
and 2015 period. Data analysis was done by changing the average value to a value in category very good, good, enough and bad to the assessment in context, input, process and product. Reference in the conversion is based on Table 1.

\subsection{RESULTS AND DISCUSSIONS}

This evaluation research is using CIPP (Context, Input, Process and Product) evaluation model. In the study, researchers must develop evaluation instruments first and addressed to stakeholders (research subjects) of KKN International. The subjecte are Physic Education Study Program UAD, International Office Affairs UAD, LPM UAD, and students who have carried out the KKN International in 2013, 2014 and 2015. Instruments developed validated by experts who understand the evaluation in the process of implementation of KKN International. In this study, the validation is done by two experts from the UAD.

The results of the validation by the expert is the content information needs as an evaluation International of KKN has been good, but there needs to be some improvements to the instrument in terms of grammar. Some remarks experts are, (1) as far as possible avoid the use "and" in one item; (2) in item, the statement "good", "fast", "clear", can be deleted, if they are removed, in the instructions give information eg; 4 = very good, 3 = good, and so on.

\subsection{Physics Education Study Program}

Data from the study program were analyzed according to the CIPP research methods that include components of context, Input, Process and Product, and converted in accordance with conversion as explained before. The result of the conversion was in table 2.

Table 2. Score and category according to study program

\begin{tabular}{ccc}
\hline Componetn & Score & Category \\
\hline Context & 3 & Good/B \\
\hline Input & 17 & Very Good /A \\
\hline Process & 7 & Very Good /A \\
\hline Product & 3,5 & Very Good /A \\
\hline
\end{tabular}

Physic education Study Program assess context of KKN International is in good category, it can be interpreted that the KKN International is an activity that considered good by the study program as an effort to improve the competence of graduate special class students in the department of physic education UAD particularly to the issue of foreign languages. To realize these activities, department of physic education is coordinating with related agencies namely KUI and LPM. In addition, the debriefing is done not only just to get performance, cost and characteristic locations, but also to mastery of the English language long day before registration. Thus, the input of this program would be in the very good category.

Evaluation process considered to be very good by the study program, because in the process of implementing this program, study program sent one lecturer as DPL (Field Supervisor) to continue the coordination of the implementation of the KKN International. The DPL duties are to deliver, monitor execution, and pick up the student. Study program also greatly support the physical education financially with their stimulant program fund.

Evaluation of products considered to be very good, because during the process of implementation until the end of the activities run smoothly and reach what was expected.One prove of it is the development of student in mastery of the English language. Because all of that, this program is recommended to be continued. 


\subsection{International Office Affair or Kantor Urusan Internasional (KUI) UAD}

Evaluation form the International Office Affairs UAD (KUI UAD) are as follows, in context, KUI considers that KKN Internasional program is very good in order to realize the UAD cooperation with foreign partners. Therefore, KUI find and contact partners in the KKN International location with good and fast. KUI also give well briefing to the students regarding the location, language, cost of living, as well as the regulation in the destination country. So inInput, KUI assess in good categories. This means that all efforts should be maximized for the implementation of the program.

Data from KUI were analyzed according to the CIPP research methods that include components of context, Input, Process and Product, and converted in accordance with conversion as explained before. The result of the conversion was in table 3.

Table 3. Score and category according to KUI

\begin{tabular}{ccc}
\hline Component & Score & Category \\
\hline Context & 4 & Very good/A \\
\hline Input & 23 & Good /B \\
\hline Process & 3 & Good /B \\
\hline Product & 4 & Very good /A \\
\hline
\end{tabular}

Implementation process of KKN International in the perspective of KUI considered good, because KUI together with DPL and LPM do well in monitoring program. KUI oversee the program until the completion and contact the rector for handover the students. In the evaluation of the product, the program is considered to be very good because during the implementation process until the end show good results, even foreign partners hope that the program can be continued the next year. Thus, this program is recommended to go ahead with the optimization of the preparation and effective coordination between KUI, LPM, Study Program and Students.

\subsection{Community Service Department or Lembaga Pengabdian Masyarakat (LPM) UAD}

Data from LPM were analyzed according to the CIPP research methods that include components of context, Input, Process and Product, and converted in accordance with conversion as explained before. The result of the conversion was in table 3.

Table 4. Score and category according to LPM

\begin{tabular}{ccc}
\hline Component & Score & Category \\
\hline Context & 4 & Very good/A \\
\hline Input & 27 & Very good/A \\
\hline Process & 5 & Good/B \\
\hline Product & 10 & Very good/A \\
\hline
\end{tabular}

Community Service Department (LPM) UAD assess context of KKN International programs in the excellent/very good category as a program to support cooperation between UAD with foreign partners. LPM has made clear rules on the program in the guide book of KKN in UAD. In input, evaluation of LPM UAD is in the very good category. LPM website informs this KKN International program. LPM do the selection and provisioning as well as providing advice on the programs that will be implemented by KKN students. In addition LPM provides manuals and assessment sheets to DPL and students which submitted during the debriefing.

LPM release, hand over, monitoring and attract students to follow KKN International well. However, in coordination with the DPL and the rector in monitoring was not good enough, resulting subjective assessment which led to all students scored 100. Therefore, the evaluation process of the program is in good category in the perspective of LPM UAD.LPM UAD conduct response and carry 
out assessment of $\mathrm{KKN}$ along with DPL appropriate with predefined rules. Implementation responseresult is very good. Thus, the product evaluation of $\mathrm{KKN}$ International is in the excellent/very good category. The program is recommended to be maintained with improvements in the process of implementation.

\subsection{Participant of KKN Internasional}

Data from Participant of KKN International were analyzed according to the CIPP research methods that include components of context, Input, Process and Product, and converted in accordance with conversion as explained before. The result of the conversion was in table 5, 6, and 7.

Table 5.Score and category according to KKN International Participant in 2013 (Cambodia)

\begin{tabular}{ccc}
\hline Component & Score & Category \\
\hline Context & 15,8 & Good/B \\
\hline Input & 15 & Good/B \\
\hline Process & 9,5 & Good/B \\
\hline Product & 9,75 & Very good/A \\
\hline \multicolumn{3}{c}{ Table 6.Score and category according to } \\
KKN International Participant in 2014 (Thailand) \\
\hline Component & Score & Category \\
\hline Context & 20,2 & Very good/A \\
\hline Input & 17 & Very good/A \\
\hline Process & 11 & Very good/A \\
\hline Product & 11,4 & Very good/A \\
\hline
\end{tabular}

Table 7.Score and category according to KKN International Participant in 2015 (Philippines)

\begin{tabular}{ccc}
\hline Component & Score & Category \\
\hline Context & 19 & Very good/A \\
\hline Input & 18 & Very good/A \\
\hline Process & 11 & Very good/A \\
\hline Product & 11 & Very good/A \\
\hline
\end{tabular}

KKN International evaluation in context, input and process from the perspective of students who implementated in the year 2013 are in good category. This is because that was the initial step of the implementation of the KKN International. Some of the constraints faced in this period was there are mistakes in informing the cost of living and the location of KKN in Cambodia. Students are expected that in the debriefing language not only English but also the local language of the country.

Product evaluation of this program is very good. The students expressed by following KKN International can increase knowledge, experience, interpret the meaning of life and growth love of the homeland. KKN International teaches sense of togetherness, familiarity, simplicity. Students recomend this program to continued with several notes including the optimization of provisioning and monitoring.

KKN International evaluation component CIPP by Student participant in 2014 and 2015 otherwise overall excellent/very good. Students get good guidance from DPL and accompanied in creating programs by DPL. Students are informed clearly about the registration of the KKN International. Students got a briefing from KUI and LPM well. In the location, $85 \%$ of students can implement programs that has been designed. As with previous period, students gain additional 
knowledge, experience and especially the improvement of foreign language skills. So this program is recommended to continue.

\subsection{CIPP Results}

The result from KUI, LPM, Physics Education Study Program, and Participant on KKN International can be shortlisted into CIPP and evaluated. In context the program is in very good category at $85 \%$ given by majority of the research subjects. Input, Process, and Product are in 81\%, $82 \%$, and $91 \%$ respectively. That results indicate that all program are doing well and in good category. All research subject are satisfied about the process of KKN International but in minor area it must be done some improvement. The program is suggested to be done in the next future and give many benefit to the participant, stakeholder (UAD), and the targeted people.

\subsection{CONCLUSIONS}

From this research several conclusions can be taken, there are :

1. Relating with Context, the program is in $85 \%$ and expressed very good by majority of the research subjects.

2. Relating with the input, the program is in $81 \%$ expressed very good by majority of the research subjects.

3. Relating with Process, the program is in $82 \%$ expressed very well by majority of the research subjects.

4. Relating with the Product, the program is in $91 \%$ expressed very well by the majority of the research subjects.

5. The program is recommended to continue in the following years, with improvements in the preparation of infrastructure such as modules / technical guide of KKN International, briefing foreign language acquisition, and patterns of coordination among the relevant institutions.

\section{REFERENCES}

Endang Susilaningsih. (2012). "Model Evaluasi Praktikum Kimia Di Lembaga Pendidikan Tenaga Kependidikan", Jurnal Penelitiandan Evaluasi Pendidikan Tahun 16, Nomor 1, 2012

Monica R. Martinez. (2016). How Deeper Learning Can Create a New Vision for Teaching, National Commission on Teaching and America's Future, Wilson Boulevard Suite 705 Arlington.

Nana Sudjana \& Ibrahim. (2004). Penelitian dan Penilaian Pendidikan, Bandung, Sinar Baru Algesindo.

Nor Hasnida Che Md Ghazali. (2016). "The implementation of School-Based Assessment System inMalaysia: A study of teacher perceptions", GEOGRAFIA Online Malaysian Journal of Society and Space, 12 issue 9 (104 117)

Norazilawati Abdullah. (2016). "The Evaluation and Effectiveness of School Based Assessment among Science Teachers in Malaysia using CIPP Model”, International Journal of Advanced and Applied Sciences, 3(11) 2016, Pages: 1-7.

PrasartNuangchalerm. (2016). "Local Service Learning in Teacher Preparation Program". Journal of Education and Learning. Vol. 10 (1) pp. 8-14.

Stufflebeam. D.L., \&Shinkfield,.A.J. (2007). Evaluation Theory, Models, and Applications, San Francisco, CA: Jossey-Bass.

Sudarsono. Fx (1994). PenelitianEvaluasi, Yogyakarta, LPM UNY.

Sukardi, DewaKetut \& Nila Kusumawati. (2008). PengantarPelaksanaan Program Bimbingan Dan Konseling Di Sekolah, (EdisiRevisi), Jakarta: Rineka Cipta,

Tim LPM UAD. (2014). Pedoman KKN UAD, LPM UAD. 